\title{
Stimulation of insulin secretion by medium-chain triglycerides in patients with cirrhosis ${ }^{1}$
}

\author{
FRANK S. MCCULLOUGH, MANUEL TZAGOURNIS, NORTON J. \\ GREENBERGER, AND WILLEM G. LINSCHEER
}

From the Division of Gastroenterology, Department of Medicine, The Ohio State University College of Medicine, and the Gastrointestinal Research Unit, Lemuel Shattuck Hospital, Boston

SUMMARY Oral medium-chain triglycerides were given to 10 normal volunteers, 12 cirrhotics (group I) without and 28 cirrhotics (group II) with abnormal portal systemic communications (ascites, splenomegaly, oesophageal varices, or surgically-created portacaval shunts). After $30 \mathrm{ml}$ of medium-chain triglyceride oil there was no appreciable change in serum glucose levels in any of the three groups nor in serum insulin levels in the normals and in cirrhotics in group I. However, there was a significant increase in serum insulin levels in the cirrhotic patients in group II. It is suggested that the rise in serum insulin levels after medium-chain triglycerides noted in the cirrhotics with shunts is due to shunting of insulin-containing portal blood around the liver (anatomical shunts) and to a diminished hepatic cell mass capable of extracting insulin (functional shunt). This differential response of serum insulin levels to medium-chain triglycerides may prove to be of value in detecting the presence of abnormal portal systemic communications in cirrhotic patients.

In recent years several factors which influence insulin secretion have been extensively studied. It has been demonstrated that several amino acids, secretin, pancreozymin, and so-called 'gut glucagon' stimulate insulin secretion (Dupre, Curtis, Unger, Wadell, and Beck, 1969; Unger and Eisentraut, 1969). In addition, long-, medium-, and short-chain fatty acids have been shown to influence insulin secretion in the experimental animal and in man (Greenberger, Tzagournis, and Graves, 1968; Crespin, Greenough, and Steinberg, 1969). Sanbar and Martin (1967) demonstrated that the C8:0 fatty acid, octanoate, stimulated the release of insulin from an in-vitro rat pancreas preparation, presumably by a direct effect on the islet beta cells. Linscheer, Slone, and Chalmers (1967) have reported that in man the intraduodenal infusion of glucose and octanoate results in higher serum insulin levels than those obtained after intraduodenal glucose alone.

Medium-chain triglycerides have been widely used as an adjunct to therapy in a wide spectrum of malabsorptive disorders (Greenberger and Skillman, 1969). Since medium-chain triglycerides contain approximately $80 \%$ octanoic acid, it seemed Received for publication 29 September 1970.

${ }^{1}$ This work was presented in part at the Regional Meeting of the American College of Physicians in Pittsburgh, Pennsylvania, on 20 November 1968. appropriate to study their effect on insulin secretion in man. It was recognized that small increments in insulin secretion induced by medium-chain triglycerides might be masked by first circulation binding and removal by the liver. To circumvent this problem preliminary studies were carried out in a small group of cirrhotic patients with portal systemic shunts as well as normal control subjects. In these studies, it was shown that the administration of medium-chain triglycerides to cirrhotic patients was associated with increased serum insulin levels (Greenberger et al, 1968).

To further define the effects of medium-chain triglycerides on insulin secretion, a large number of patients with cirrhosis of the liver were studied. The data obtained indicate that the serum insulin response to medium-chain triglycerides is significantly greater in cirrhotic patients with clinical evidence of portal systemic communications as compared with cirrhotic patients without evidence of portal hypertension.

\section{Methods}

Ten healthy male volunteers, aged between 22 and 35 without any family history of diabetes mellitus, served as controls. Forty cirrhotic patients were distributed into two groups based on the presence 
or absence of splenomegaly, ascites, oesophageal varices, hepatic encephalopathy, or surgically created portal systemic anastomoses. Twelve patients with cirrhosis of the liver, but without any evidence of portal systemic communications, comprised group I. None of the patients in group I had splenomegaly, ascites, or oesophageal varices. Twenty-eight patients with cirrhosis of the liver and documented portal systemic communications (group II) had clinical evidence of portal hypertension. Nineteen patients in this group had ascites, 14 had splenomegaly, seven had a previous history of hepatic encephalopathy, six had surgically created portacaval anastomoses, and 18 had oesophageal varices demonstrated by oesophagoscopy or barium radiography. All patients in groups I and II had cirrhosis of the liver proved by biopsy. None of the patients studied were receiving corticosteroids or thiazide diuretics at the time of study and serum potassium levels were normal in all subjects. All had been ingesting at least $300 \mathrm{~g}$ of carbohydrate daily for at least three days before study. The informed consent of each patient was obtained before study in accordance with the Declaration of Helsinki.

Oral glucose tolerance tests were carried out using a dose of $100 \mathrm{~g}$ and the criteria of O'Sullivan (1967) were utilized in establishing a diagnosis of diabetes mellitus. According to these criteria, a diagnosis of diabetes mellitus is established when any three or more of the following values or the fasting and three-hour combination are met or exceeded giving a total of two points: fasting blood sugar greater than $110 \mathrm{mg} \%=1$ point; one-hour value greater than $170 \mathrm{mg} \%=\frac{1}{2}$ point; two-hour value greater than
$120 \mathrm{mg} \%=\frac{1}{2}$ point; three-hour value greater than $110 \mathrm{mg} \%=1$ point. After an overnight fast medium-chain triglycerides were given by mouth as an oil preparation ${ }^{1}$ in a 'dose of $30 \mathrm{ml}(28.5 \mathrm{~g})$. The medium-chain triglyceride oil contained $80 \%$ trioctanoin (C8:0) and 17\% tridecanoin (C10:0). Serum glucose and serum insulin levels were determined before medium-chain triglycerides were given, and at 30, 60, and 120 minute intervals thereafter. In 10 patients serum octanoate levels were also determined before medium-chain triglycerides were given, and at 30, 60, and $120 \mathrm{ml}$ intervals. Serum glucose was determined on the Technicon AutoAnalyzer by the method of Hoffman (1937). Serum insulin levels were determined in duplicate by the immunochemical method of Grodsky and Forsham (1960). Serum octanoate levels were determined by gas liquid chromatography as previously described by Linscheer et al (1967). All serum glucose, insulin, and octanoate determinations were performed by technicians who were unaware of the clinical classification of the patient. Statistical analysis was performed using Student's t test.

\section{Results}

Clinical data on the patients with cirrhosis of the liver are shown in Table I. Two of the patients in group I and nine of the patients in group II had diabetes mellitus according to the criteria of O'Sullivan (1967). Tests of liver function in the cirrhotic patients studied are shown in Table II.

${ }^{1}$ Kindly supplied by Dr Herbert P. Sarett of Mead Johnson Laboratories.

\begin{tabular}{|c|c|c|c|c|c|c|c|c|c|c|c|c|c|}
\hline \multirow[t]{2}{*}{ Froup ${ }^{1}$} & \multirow{2}{*}{$\begin{array}{l}\text { No. of } \\
\text { Patients }\end{array}$} & \multicolumn{2}{|l|}{ Sex } & \multirow{2}{*}{$\begin{array}{l}\text { Diabetes } \\
\text { Mellitus }^{2}\end{array}$} & \multicolumn{3}{|c|}{ Type of Cirrhosis } & \multicolumn{6}{|c|}{ Complications of Cirrhosis } \\
\hline & & Male & Female & & Laennec's & $\begin{array}{l}\text { Post- } \\
\text { necrotic }\end{array}$ & Other & Ascites & Splenomegaly & $\begin{array}{l}\text { Oesophageal } \\
\text { Varices }\end{array}$ & $\begin{array}{l}\text { Gastrointestinal } \\
\text { Bleeding }\end{array}$ & $\begin{array}{l}\text { Surgical } \\
\text { Shunt }\end{array}$ & $\begin{array}{l}\text { Prior Hepatic } \\
\text { Encephalopathy }\end{array}$ \\
\hline $\begin{array}{l}\text { Jroup I } \\
\text { Jroup II }\end{array}$ & $\begin{array}{l}12 \\
28\end{array}$ & $\begin{array}{l}10 \\
16\end{array}$ & $\begin{array}{r}2 \\
12\end{array}$ & $\begin{array}{l}2 \\
9\end{array}$ & $\begin{array}{l}11 \\
22\end{array}$ & $\begin{array}{l}1 \\
3\end{array}$ & $\begin{array}{l}\mathbf{0} \\
3^{3}\end{array}$ & $\begin{array}{r}0 \\
19\end{array}$ & $\begin{array}{r}0 \\
14\end{array}$ & $\begin{array}{r}0 \\
18\end{array}$ & $\begin{array}{r}0 \\
13\end{array}$ & $\begin{array}{l}0 \\
6\end{array}$ & $\begin{array}{l}0 \\
7\end{array}$ \\
\hline
\end{tabular}

Table I Clinical data on cirrhotic patients

Group I, cirrhotics with no evidence of portal systemic communications; group II, cirrhotics with evidence of portal systemic communications. According to the criteria of O'Sullivan (1967).

Includes two patients with primary biliary cirrhosis and one with Wilson's disease.

\begin{tabular}{|c|c|c|c|c|c|c|c|}
\hline \multirow[t]{2}{*}{ Group } & \multirow{2}{*}{$\begin{array}{l}\text { No. of } \\
\text { Patients }\end{array}$} & \multicolumn{2}{|c|}{ Serum Proteins ( $(\mathrm{\%})$} & \multirow{2}{*}{$\begin{array}{l}\text { Total Serum Bilirubin } \\
(m g \% ; \text { normal } \leqslant 1 \cdot 5)\end{array}$} & \multirow{2}{*}{$\begin{array}{l}\text { Serum Alkaline } \\
\text { Phosphatase (SJR units; } \\
\text { normal } \leqslant 4 \cdot 5)\end{array}$} & \multirow{2}{*}{$\begin{array}{l}\text { Prothrombin } \\
\text { Time }(\% \text { of } \\
\text { control; } \\
\text { normal } \geqslant 70 \cdot 0)\end{array}$} & \multirow{2}{*}{$\begin{array}{l}\text { Retention of } \\
\text { BSP }(0 \% \text { at } \\
45 \text { min; } \\
\text { normal }<5.0)\end{array}$} \\
\hline & & $\begin{array}{l}\text { Albumin } \\
(\text { normal } \geqslant 3.5)\end{array}$ & $\begin{array}{l}\text { Globulin } \\
\text { (normal } \leqslant 3 \cdot 0)\end{array}$ & & & & \\
\hline $\begin{array}{l}\text { Group I } \\
\text { Group II }\end{array}$ & $\begin{array}{l}12 \\
28\end{array}$ & $\begin{array}{l}3 \cdot 7 \pm 0 \cdot 2^{1} \\
3 \cdot 4 \pm 0 \cdot 2\end{array}$ & $\begin{array}{l}3.5 \pm 0.2 \\
3.7 \pm 0.2\end{array}$ & $\begin{array}{l}2.9 \pm 1.5 \\
4.0 \pm 0.9\end{array}$ & $\begin{array}{l}7.6 \pm 1.6 \\
6.4 \pm 1.0\end{array}$ & $\begin{array}{l}80 \cdot 0 \pm 7 \cdot 0 \\
62 \cdot 0 \pm 5 \cdot 0^{2}\end{array}$ & $\begin{array}{l}22 \cdot 5 \pm 5 \cdot 0 \\
26 \cdot 0 \pm 3 \cdot 0\end{array}$ \\
\hline
\end{tabular}

Table II Test of liver function in the cirrhotic patients

Mean \pm SE.

${ }^{2}$ Significantly different from group I; P $<0.05$. 
Although the values shown were generally more abnormal in the group II patients, the only index which was significantly different between the two groups was the prothrombin time, $80 \pm 7 \%$ vs $62 \pm 5 \%( \pm 1 \mathrm{SE}, \mathrm{P}<0.05)$. The effects of mediumchain triglycerides on serum insulin levels and serum glucose levels on normal controls and the two groups of cirrhotics are shown in Table III. There were no significant differences among the three groups in the fasting state. After the administration of medium-chain triglycerides there was little change in the mean serum insulin and glucose levels in both the controls and the cirrhotic patients in group I. However, there was a significant increase in the mean serum insulin levels at 30,60 , and 120 minutes after medium-chain triglycerides in the group II cirrhotics. The mean serum insulin levels increased from a fasting value of $14.0 \pm 1 \cdot 1 \mu \mathrm{U} / \mathrm{ml}$ $( \pm 1 \mathrm{SE})$ to a peak value of $28.0 \pm 3.4 \mu \mathrm{U} / \mathrm{ml}$ at 30 minutes. Also shown in Table III are mean serum insulin values in the 19 cirrhotic patients in group II who had normal oral glucose tolerance tests. Even when the patients whose peripheral insulin levels might be expected to be abnormally elevated because of diabetes mellitus are excluded, the mean serum insulin levels at 30 and 60 minutes after mediumchain triglycerides are still significantly elevated at $29.6 \pm 4.5$ and $25 \pm 3.9 ' \mu \mathrm{U} / \mathrm{ml}$ respectively compared to controls. It can also be seen that after administration of medium-chain triglycerides there was little change in mean serum glucose levels in group II cirrhotics (Table III).

The effects of $100 \mathrm{~g}$ of glucose on serum glucose and serum insulin are shown in Table IV. The mean serum insulin levels tended to be higher in the group II cirrhotics, but only the values after 120 minutes were significantly different than in the group I patients. Similarly, the mean serum glucose levels tended to be higher in the group II patients with significant differences obtained at 60 and 120 minutes. These differences can probably be accounted for by the greater number of patients ( 9 vs 2 ) with diabetes mellitus in group II.

Only trace amounts of octanoate were detectable

\begin{tabular}{|c|c|c|c|c|c|c|c|c|c|}
\hline \multirow[t]{2}{*}{ Group } & \multirow{2}{*}{$\begin{array}{l}\text { No. of } \\
\text { Subjects }\end{array}$} & \multicolumn{4}{|c|}{ Serum Insulin $(\mu U / m l)$ after $M C T$} & \multicolumn{4}{|c|}{ Serum Glucose $(\mathrm{mg} / 100 \mathrm{ml})$ after $M C T$} \\
\hline & & Fasting & $30 \mathrm{~min}$ & $60 \mathrm{~min}$ & $120 \mathrm{~min}$ & Fasting & $30 \mathrm{~min}$ & $60 \mathrm{~min}$ & $120 \mathrm{~min}$ \\
\hline $\begin{array}{l}\text { Normal controls } \\
\text { Group I } \\
\text { Group II } \\
\text { Selected group II cirrhotics }\end{array}$ & $\begin{array}{r}10 \\
12 \\
28 \\
119\end{array}$ & $\begin{array}{l}10 \cdot 0 \pm 0 \cdot 6 \\
11 \cdot 0 \pm 0 \cdot 8 \\
14 \cdot 0 \pm 1 \cdot 1 \\
13 \cdot 5 \pm 1 \cdot 4\end{array}$ & $\begin{aligned} 9 \cdot 0 & \pm 0 \cdot 9 \\
12 \cdot 0 & \pm 0 \cdot 8 \\
28 \cdot 0 & \pm 3 \cdot 4^{1} \\
29 \cdot 6 & \pm 4 \cdot 5^{1}\end{aligned}$ & $\begin{array}{l}10 \cdot 0 \pm 0 \cdot 4 \\
12 \cdot 0 \pm 0 \cdot 8 \\
25 \cdot 0 \pm 2 \cdot 7^{1} \\
25 \cdot 0 \pm 3 \cdot 9^{1}\end{array}$ & $\begin{array}{l}11 \cdot 0 \pm 0 \cdot 8 \\
10 \cdot 0 \pm 0 \cdot 3 \\
21 \cdot 0 \pm 3 \cdot 3^{2} \\
16 \cdot 0 \pm 3 \cdot 5\end{array}$ & $\begin{array}{l}94 \cdot 0 \pm 4 \cdot 0 \\
96 \cdot 0 \pm 5 \cdot 0 \\
89 \cdot 0 \pm 3 \cdot 0 \\
88.0 \pm 2 \cdot 4\end{array}$ & $\begin{array}{l}90 \cdot 0 \pm 3 \cdot 0 \\
99 \cdot 0 \pm 4 \cdot 0 \\
92 \cdot 0 \pm 4 \cdot 0 \\
93 \cdot 0 \pm 3 \cdot 1\end{array}$ & $\begin{array}{l}91 \cdot 0 \pm 3 \cdot 0 \\
99 \cdot 0 \pm 4 \cdot 0 \\
94 \cdot 0 \pm 3 \cdot 0 \\
96 \cdot 0 \pm 2 \cdot 6\end{array}$ & $\begin{array}{l}91 \cdot 0 \pm 4 \cdot 0 \\
96 \cdot 0 \pm 4 \cdot 0 \\
94 \cdot 0 \pm 3 \cdot 0 \\
82 \cdot 0 \pm 3 \cdot 3\end{array}$ \\
\hline
\end{tabular}

Table III Effect of medium-chain triglycerides (MCT) on serum insulin and glucose levels in control subjects and cirrhotic patients

'Significantly different from control values, $P<0.01$

'Significantly different from control values, $\mathrm{P}<0.05$

${ }^{3}$ Group II cirrhotics with normal glucose tolerance tests. All those with abnormal glucose tolerance tests have been excluded.

\begin{tabular}{|c|c|c|c|c|c|c|c|c|c|}
\hline \multirow[t]{2}{*}{ Group } & \multirow{2}{*}{$\begin{array}{l}\text { No. of } \\
\text { Subjects }\end{array}$} & \multicolumn{4}{|c|}{ Serum Insulin $(\mu U / m l)$ after Glucose } & \multicolumn{4}{|c|}{ Serum Glucose $(\mathrm{mg} / 100 \mathrm{ml})$ after Glucose } \\
\hline & & Fasting & $30 \mathrm{~min}$ & $60 \mathrm{~min}$ & $120 \mathrm{~min}$ & Fasting & $30 \mathrm{~min}$ & $60 \mathrm{~min}$ & $120 \mathrm{~min}$ \\
\hline $\begin{array}{l}\text { Group I } \\
\text { Group II }\end{array}$ & $\begin{array}{r}8 \\
18\end{array}$ & $\begin{array}{l}12.0 \pm 1.6 \\
15.0 \pm 3.0\end{array}$ & $\begin{array}{l}84 \cdot 0 \pm 18.0 \\
80 \cdot 0 \pm 12 \cdot 0\end{array}$ & $\begin{aligned} 78.0 & \pm 18.0 \\
103.0 & \pm 13.0\end{aligned}$ & $\begin{array}{r}60.0 \pm 14.0 \\
108.0 \pm 13.0^{1}\end{array}$ & $\begin{array}{l}89.0 \pm 4.0 \\
90.0 \pm 4.0\end{array}$ & $\begin{array}{l}157.0 \pm 4.0 \\
164.0 \pm 12.0\end{array}$ & $\begin{array}{l}154.0 \pm 7.0 \\
188.0 \pm 15.0^{2}\end{array}$ & $\begin{array}{l}128 \cdot 0 \pm 6 \cdot 0 \\
160 \cdot 0 \pm 5 \cdot 0^{2}\end{array}$ \\
\hline
\end{tabular}

Table IV Effect of $100 \mathrm{~g}$ of glucose on serum insulin and glucose levels in cirrhotic patients

'Significant difference; $\mathrm{P}<0.05$.

${ }^{2}$ Significant difference: $\mathbf{P}<0.01$.

\begin{tabular}{|c|c|c|c|c|c|c|c|c|c|}
\hline \multirow[t]{2}{*}{ Group } & \multirow{2}{*}{$\begin{array}{l}\text { No. of } \\
\text { Subjects }\end{array}$} & \multicolumn{4}{|c|}{ Serum Octanoate ( $\mu$-equiv/l) after $M C T$} & \multicolumn{4}{|c|}{ Serum Insulin $(\mu U)$ after $M C T$} \\
\hline & & Fasting & $30 \mathrm{~min}$ & $60 \mathrm{~min}$ & $90 \min$ & Fasting & $30 \mathrm{~min}$ & $60 \mathrm{~min}$ & $90 \min$ \\
\hline $\begin{array}{l}\text { Group I } \\
\text { Group II }\end{array}$ & $\begin{array}{l}2 \\
8\end{array}$ & $\overline{-}^{2}$ & $\begin{array}{l}79 \\
321 \pm 60^{2}\end{array}$ & $\begin{array}{l}78 \\
279 \pm 43\end{array}$ & $\begin{array}{l}154 \\
343 \pm 40\end{array}$ & $\begin{array}{l}10 \\
14 \pm 2 \cdot 2\end{array}$ & $\begin{array}{l}10 \\
29 \pm 4 \cdot 5\end{array}$ & $\begin{array}{l}10 \\
21 \pm 4.0\end{array}$ & $\begin{array}{l}10 \\
11 \pm 1 \cdot 3\end{array}$ \\
\hline
\end{tabular}

Table $\mathrm{V}$ Effect of medium-chain triglycerides $(M C T)$ on peripheral serum octanoate and insulin levels in patients with cirrhosis of the liver ${ }^{1}$

'Patients received medium-chain triglyceride oil $(30 \mathrm{ml})$.

Only trace amounts of octanoate were detectable in fasting blood specimens in any of the 10 patients. 


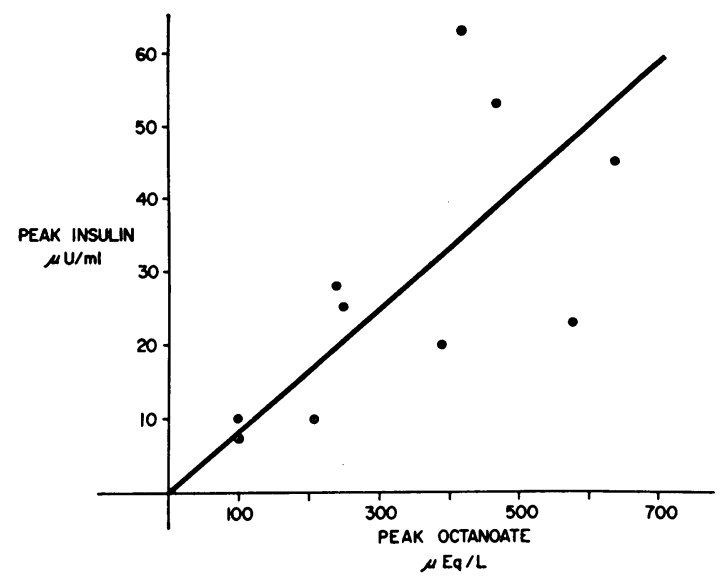

Fig. 1. The relationship between the peak serum insulin value observed after the oral administration of $30 \mathrm{ml}$ of medium-chain triglyceride oil and the peak serum octanoate value in 10 patients with cirrhosis of the liver. Patients with evidence of abnormal portal systemic communications are depicted by the solid circles and those without shunts by the open circles $(r=0.84 ; \mathrm{P}<0.01)$.

in fasting blood specimens in any of the 10 patients. The effect of medium-chain triglycerides on peripheral serum octanoate and insulin levels are shown in Table V. The peak serum octanoate levels and peak serum insulin levels observed after administration of medium-chain triglycerides are depicted in Figure 1. Of the 10 patients studied, two were from group I and eight were from group II. Two of the lowest peak octanoate values (99 and 209 $\mu$-equiv/l) were obtained in the two patients from group I. There was a significant correlation between the peak serum octanoate and peak serum insulin levels $(r=0.84 ; P<0.01)$.

\section{Discussion}

Previous studies have shown that trioctanoin, the major component of medium-chain triglycerides, is rapidly hydrolysed by pancreatic lipase to octanoic acid (Greenberger, Rogers, and Isselbacher, 1966). Octanoate is then absorbed and transported via the portal vein to the liver where it is rapidly metabolized. In patients with cirrhosis given a mediumchain triglyceride oil preparation, increased levels of octanoic acid in peripheral blood might result for two reasons: (1) a reduced capacity of a diseased liver to metabolize medium-chain fatty acids, and (2) shunting of octanoate away from the liver via spontaneous or surgically created portal systemic communications. In this regard, Linscheer and his coworkers (Linscheer et al, 1967; Linscheer, Castell, and Platt, 1969) have previously demonstrated that medium-chain triglycerides given either intraduodenally or rectally results in higher peripheral blood octanoate levels in cirrhotic patients with portacaval shunts than in normal control subjects.

The data obtained in the present investigation indicate that mean serum insulin levels increase appreciably after the administration of mediumchain triglycerides to cirrhotic patients with evidence of portal systemic communications as compared with normal control subjects and cirrhotic patients without evidence of such shunts. The specific mechanism by which medium-chain triglycerides may cause elevated peripheral blood insulin levels has not been defined by the present studies. Octanoate per se might exert a direct stimulatory effect on the pancreatic islet beta cell. It will be recalled that medium-chain triglycerides caused considerable increase in peripheral blood octanoate levels (Fig. 1). However, the possibility cannot be excluded that octanoate causes release from the intestinal mucosa of hormones such as secretin, pancreozymin, and 'gut' glucagon which may stimulate insulin release. In addition to increased peripheral blood octanoate levels there are other factors which might explain the elevated peripheral blood insulin levels in the cirrhotics in group II. A reduced liver cell mass is capable of binding less insulin during its initial passage through the liver resulting, in essence, in a functional shunt. In addition, actual anatomical shunts around the liver via portal systemic communications might result in higher peripheral blood insulin levels. It is possible that medium-chain triglycerides caused a modest increase in insulin secretion in both groups of cirrhotics, but the increase was more easily detectable in the group II cirrhotics because of shunting of insulin-containing portal blood around the liver. This hypothesis is supported by the finding that peripheral blood insulin levels were higher in group II cirrhotics compared to group I cirrhotics 60 and 120 minutes after a glucose load (Table IV).

Some caution must be exercised, however, in interpreting the results of the glucose tolerance tests and serum insulin values in patients with chronic liver disease. As pointed out in the methods section, we were careful to exclude from study patients whose carbohydrate tolerance might be abnormal because of an inadequate caloric intake, hypokalaemia, and the use of drugs such as thiazide diuretics and corticosteroids, all of which are known to have a diabetogenic effect on carbohydrate tolerance. There remained 11 patients of a total of 40 with abnormal glucose tolerance tests. In none of these patients was there previous evidence to suggest the diagnosis of diabetes mellitus. Although 
these patients fulfilled the criteria employed for the diagnosis of diabetes, it could be argued that they have the carbohydrate intolerance of the cirrhotic or so-called 'hepatogenous diabetes' (Conn, Schreiber, Elkington, and Johnson, 1969) instead of genetic diabetes. In this regard, it has been demonstrated that patients with advanced cirrhosis may exhibit resistance to the blood glucose-lowering effect of insulin (Megyesi, Samols, and Marks, 1967; Collins and Crofford, 1969).

Despite the above limitations, the data obtained in the present study suggest that the metabolic response of cirrhotic patients to medium-chain triglycerides might be useful in establishing the presence or absence of abnormal portal systemic communications. Although we have studied only 10 normal controls and 12 cirrhotic patients without clinical evidence of portal systemic shunts, none of these 22 patients demonstrated a significant rise in peripheral blood insulin levels after medium-chain triglycerides. By contrast, 22 of 28 patients with clinical evidence of abnormal portal systemic communications exhibited at least one peripheral blood insulin value which was significantly greater than the fasting value after oral administration of medium-chain triglycerides. In view of these findings, a prospective controlled study of the effects of medium-chain triglycerides on insulin secretion in cirrhotic patients would seem to be in order to define critically its diagnostic value.

The authors are grateful to Dr John Flanagan and Mrs Elizabeth Catalano for expert technical assistance and Dr Harold O. Conn for his critical review of the manuscript.

The work was supported in part by grants (FR-34 and AM-11566-02) from the National Institutes of Health.

Please address requests for reprints to Dr Norton
J. Greenberger, Ohio State University Hospital, 410 West 10th Avenue, Columbus, Ohio 43210, USA.

\section{References}

Collins, J. R., and Crofford, O. B. (1969). Glucose intolerance and insulin resistance in patients with liver disease. Arch. intern. Med., 124, 142-148.

Conn, H. O., Schreiber, W., Elkington, S. G., and Johnson, T. R, (1969). Cirrhosis and diabetes. I. Increased incidence of diabetes in patients with Laennee's cirrhosis. Amer. J. dig. Dis., 14, 837-852.

Crespin, S. R., Greenough, W. B. III, and Steinberg, D. (1969). Stimulation of insulin secretion by infusion of free fatty acids. J. clin. Invest., 48, 1934-1943.

Dupre, J., Curtis, J. D., Unger, R. H., Wadell, R. W., and Beck, J. C. (1969). Effects of secretin, pancreozymin, or gastrin on the response of the endocrine pancreas to administration of glucose or arginine in man. J. clin. Invest., 48, 745-757.

Greenberger, N. J., Rogers, J. B., and Isselbacher, K. J. (1966). Absorption of medium and long chain triglycerides: Factors influencing their hydrolysis and transport. J. clin. Invest., 45, 217-227.

Greenberger, N. J., and Skillman, T. G. (1969). Medium chain triglycerides. Physiologic considerations and clinical implications. New Engl. J. Med., 280, 1045-1058.

Greenberger, N. J., Tzagournis, M., and Graves, T. M. (1968). Stimulation of insulin secretion in man by medium chain triglycerides. Metabolism, 17, 796-801.

Grodsky, G. M., and Forsham, P. H. (1960). An immunochemical assay of total extractable insulin in man. J. clin. Invest., 39, 1070-1079.

Hoffman, W. S. (1937). A rapid photoelectric method for the determination of glucose in blood and urine. J. biol. Chem., 120, $51-55$.

Linscheer, W. G., Castell, D. O., and Platt, R. R. (1969). A new method for evaluation of portasystemic shunting: The rectal octanoate tolerance test. Gastroenterology, 57, 415-423.

Linscheer, W. G., Slone, D., and Chalmers, T. C. (1967). Effects of octanoic acid on serum levels of free fatty acids, insulin, and glucose in patients with cirrhosis and in healthy volunteers. Lancet, 1, 593-597.

Megyesi, C., Samols, E., and Marks, V. (1967). Glucose tolerance and diabetes in chronic liver disease. Lancet, 2, 1051-1056.

O'Sullivan, J. B. (1967). Oral tolerance test. In Diabetes Mellitus Diagnosis and Treatment, edited by G. J. Hamwi and T. S. Danowski, Vol. I, p. 47. American Diabetes Association, New York.

Sanbar, S. S., and Martin, J. M. (1967). Stimulation by octanoate of insulin release from isolated rat pancreas. Metabolism, 16, 482-484.

Unger, R. H., and Eisentraut, A. M. (1969). Entero-insulin axis. Arch. intern, Med., 123, 261-266. 